Challenges and pitfalls for workplace unionism in a restructured public service

\title{
Cécile Guillaume
}

\section{Gill Kirton}

\begin{abstract}
In the context of restructuring that has swept across Europe in recent years, this article discusses the conditions of workplace unionism resilience in a small predominantly female UK public service occupation - probation. Using both quantitative and qualitative data, the article offers comprehensive insights into members' expectations towards their union branches and provides evidence of even more accountable and responsive relationships between local reps and their members following restructuring. Factors that contributed to the resilience of the union included the influence of a shared occupational identity, the legacy of large and confident branches, and the (gender) democratic tradition of the union. However, the research also highlights some limitations for the permanence of effective workplace unionism in a context of socio-demographic changes as well as organizational difficulties linked to the restructuring and outsourcing process.
\end{abstract}

\section{Keywords}

Union resilience, restructuring, outsourcing, probation, workplace unionism, gender

\section{Introduction}

In May 2013, amid much consternation and criticism from criminal justice academics, union officers/officials, and senior figures in the probation service of England and 
Wales, the then Justice Secretary, Chris Grayling, publicly unveiled Transforming Rehabilitation (TR) - a programme of restructuring and outsourcing, which would split in two the probation service that had been in existence for over 100 years. One part remained in the public sector and the other part was outsourced to private providers. TR followed in the wake of a turbulent recent history in the probation service involving other major structural reforms that had proved contentious and had profoundly altered the working lives of probation practitioners (Gale, 2012; Mawby and Worrall, 2013). This research investigated the effects of this latest major reform, Transforming Rehabilitation, on the operations/activities of the specialist union (Napo) representing probation practitioners, 70 per cent of whom are women. Our aim here is to discuss whether local union organization is strengthened or weakened by radical restructuring of a public service/occupation.

The article contributes to the important industrial relations topic of public sector reform. A recent pan-European study on public sector restructuring finds that processes are often carried out hastily, are often not transparent and often involve limited consultation with social partners. The lack of consultation with trade unions experienced in some countries, and attendant implications for restructuring processes and effects, is particularly noteworthy given that trade union coverage in EU countries is typically higher in the public sector. Similar to other European countries (Bach and Bordogna, 2013; Flecker and Hermann 2011), but on a much greater scale, the UK public sector has undergone many trenchant reforms over a period spanning at least three decades. Just as in other European countries, these reforms have negatively affected employment numbers and working conditions, and have led to fragmentation of industrial relations in what was historically a highly unionised sector (Eurofound 
2015; Flecker and Hermann 2014). Since 1997, in the UK we have seen outsourcing of welfare state activities (e.g. in hospitals, schools, residential care), defence activities (e.g. barracks, transport), and criminal justice activities (e.g. in prisons, courts, police stations) (Whitfield 2002). Many of these outsourcing exercises have occurred in feminized work contexts, thereby disproportionately impacting upon women workers and feminized trade unions. It is quite clear that outsourcing is not abating and that it has in fact most likely entered a new phase in the UK, which is likely to affect more groups of highly skilled/professional (female) workers as well as continue to affect low skill (often feminized) jobs. The Conservative-Liberal Democrat coalition government (2010-2015) gained power in the wake of the global financial crisis with a manifesto commitment to a programme of public spending cuts and so-called austerity measures to reduce the deficit (Bach, 2016). The post-Brexit economic uncertainties facing the Conservative government (2015-present) are unlikely to reverse this trend.

Nevertheless, UK public sector unions have remained relatively resilient in a context of three decades of considerable upheaval, but the unions are undoubtedly vulnerable and they have arguably necessarily taken a defensive stance, resorting to cooperative forms of collective bargaining such as social partnership agreements (Brown, 2011; Author A \& B, XXXX). Earlier studies of privatization and outsourcing in other industries/occupations have revealed the potential for negative impact on a union's ability to represent members effectively, bargain on behalf of members, and recruit and retain members in the newly created multi-employer context. This article examines the challenges that TR poses to workplace unionism, by focusing on the role of local branch activists in Napo. Established in 1913, Napo is a small professional union (7000 members in 2015, approximately $70 \%$ women) that 
represents probation practitioners and a small number of administrative employees within probation. Local union branch officers in public sector workplaces are typically accustomed to recruiting and representing members in a single employer. Sustaining local representation and branch activism represents a huge challenge in a context of possible reduction in facility time, bigger risks of union victimization (Author B, XXXX), increased workforce instability, segmented and dispersed constituencies (Cumbers et al., 2010). The whole process of restructuring and outsourcing creates higher demands and tensions across these various activities and questions the relations between members, workplace representatives and national officers/officials in the local union organization (Terry, 1996; Kessler and Heron, 2001).

This article offers original insights into members’ expectations towards their local representatives and their union in a feminized small public sector union by drawing upon survey and interview data. First, it addresses the difficulties for Napo to maintain strong workplace organization in the restructured environment. Second, it looks into the challenges of union participation amongst a highly feminised workforce. Third, the article explores the various sources of union legitimacy in a context where union reps have to find a balance between their professional, educational and union roles. Finally, by reflecting on different subjective and objective dimensions of union participation, the article addresses the issue of workplace unionism resilience in the probation context.

\section{Restructuring, outsourcing and union organization}

In the industrial relations literature, shop stewards’ legitimacy and workplace unionism are two classic and interrelated questions. In the 1970s, these two issues 
materialized in the context of the development of shop steward organization across British industry, including the public sector, and of the decentralization of collective bargaining (Terry, 1983). More recently, the promotion of workplace partnerships (Harrison, Roy and Haines III, 2011; Butler and Tregaskis, 2015) and the need to attract and retain members, including women and under-represented groups, have brought back the issue of union reps' accessibility and representational effectiveness at the workplace level (Taylor and Moore, 2014). In the UK, like in other European countries, upholding or increasing union presence in the workplace has been described as crucial for keeping and winning union members (Schnabel, 2013) and for responding to collective bargaining decentralization.

However, many studies reveal that shop-steward organization has become profoundly disorientated by the formalization of working relationships (Taylor and Moore, 2014), and the imposition of constant restructuring and outsourcing (Darlington, 1995). In the public sector, w civil servants' unionism typically consisted of inactive membership led by national officials, emphasis on pragmatic accommodation to government and management policies and a preference for negotiation (Fisher, 2004). The new environment has forced unions to confront their organization and reorient away from centralized and hierarchical traditions towards member-led activism (Fairbrother, 2006; Cumbers et al. 2010). Looking into other areas of the public sector, some authors talk about the resilience of workplace unionism and show evidence of reengagement and closer relationships between unions reps and the membership that are encouraged by privatization (McBride, 2004; Darlington, 2009). If the reduction in the number of union representatives and the availability of time off (facility time) present a real challenge for unions especially for feminized ones (Author B, XXXX), privatization can also create the conditions for a more responsive 
and accountable relationship between union representatives and their members (Darlington, 1993).

Because privatization challenges traditional union jurisdiction, creates new types of representation gap and obliges unions to deal with a proliferation of employers, some studies anticipate limited prospects for union effectiveness without good inter-union relationships, supportive rather than dominant officers, and cooperative managerial approach to stewards’ participation (Lloyd, 1997). In a study of British Rail privatization (Cumbers and al. 2010), research demonstrates an impetus to find new ways of connecting the grassroots with the national leadership because of the need to organize effectively at lower geographical scales within individual enterprises. It also insists on the discursive resource that consists of local reps' embedded knowledge and experience of rail work to promote an alternative agenda. Likewise, Colling’s (1993) research about the union effects of Compulsory Competitive Tendering (CCT) in local authorities in the 1980s and early 1990s shows that activists and paid officials faced big increases in the demands made of them by members looking for individual advice and support. Increased branch activity is deemed necessary to tackle the decentralized context, but with co-ordination and servicing from national level. Even strong branches may become reliant on advice and input from national paid officials in the complex and uncertain environment. One significant problem Colling (ibid) identifies is that distribution of paid official services risks becoming driven by demand rather than by need, such that strong branches get stronger and weak ones weaker.

Cunningham and James’ (2010) study of outsourcing of social care work (also a feminized context) reveals how Unison in particular among UK public service unions, has had to accommodate and adapt to the realities and challenges of outsourcing. 
Challenges have included how to structure branches to include members located in a variety of geographically dispersed workplaces where it can be difficult to create selfsustaining groups of activists. In addition, how to deal with union-hostile employers, a situation that public sector unions are historically unaccustomed to. Linked to this, unions often face for the first time a situation where private employers refuse to negotiate with lay officers who are not their employees. For some union branches, this might mean recruiting new workplace reps and branch officers from within the outsourced areas of the service; this in turn can be challenging because staff can be more reluctant to get involved with their union when faced with hostile or at least uncooperative employers (Whitfield, 2002). The shortage of experienced activists due to retirement or voluntary redundancies, combined with the difficulties of recruiting new reps (Carter and Poynter, 1999), can create huge challenges for small trade unions in particular. The Unison experience also highlights the importance of facilities agreements that give access to new starters at induction events; mobilizing member perceptions of the union contribution to resolving common concerns such as changes to terms and conditions, and sustaining a pool of branch activists ready and able to service individual members at the workplace (Cunningham and James, 2010). In the more pressurized context, this can be difficult and members are often reluctant to take on, or they may even want to give up, a union role because of an intensified workload combined with family responsibilities. There is abundant evidence that this especially affects women activists (Author B, XXXX; Munro 2001; Colgan and Ledwith 2000).

Finally, this issue of resilience of workplace unionism opens up new questions in the context of professional unions (Burchill, 1995) that have to combine industrial, professional and educational goals (Kessler and Heron, 2001). Besides having to 
rethink their relationships between local and national levels and with the membership, professional unions need to re-balance their occupational focus and economic concerns in the context of more segmented and dispersed constituencies and difficult relationships with management. If the diversification of the workforce is not necessarily detrimental to collectivism which can spring from ethnic and gender identification rather than class or occupation (Healy et al, 2004), it can be constrained by managerial negative attitudes towards trade unions and the risk of victimization (Author B, XXX). While these issues have been discussed in the literature (cited above), there is rarely an explicit gender dimension even where predominantly female workforces and union memberships constitute the case context (e.g. Kessler and Heron's study on nurses/the RCN). Evidence suggests that strong workplace unionism can be prevalent in workplaces displaying or combining different characteristics: strong occupational community, key (left wing) stewards and a committed activist milieu (Darlington, 1997; 2009), and participatory union leadership (Greene et al. 2000). Moreover, specific case studies on emotional labour and care work, mostly carried out by female workers, have shown that union legitimacy is linked to its capacity to represent workers' sense of their interests both as workers and as advocates of customer service and to build on the informal collectivism that stems form the experience of work (Saundry and McKeown, 2013; Taylor and Moore, 2014).

\section{Research methods}

The primary research was undertaken early on after implementation of TR, between January and July 2015. Access was via the union Napo, which mirroring the gender composition of probation, had a 70\% female membership. Multiple methods were 
used, including quantitative (a Napo membership survey), and qualitative (i.e. Napo officer/official interviews, member focus groups, observation of union events). The survey covered various topics related to working and employment conditions, such as workplace culture, job satisfaction, union participation and experience. The findings allow us to include the experiences and views of a larger population of probation workers beyond those most active in the union and to give a strong sense of the magnitude of particular problems and challenges. The qualitative methods give us a chance to delve deeper into significant issues and therefore the analytical emphasis is on the qualitative interviews with Napo officials/officers. We believe the multiple methods provide a comprehensive understanding of the current state of workplace unionism in probation within the context of Napo member experiences of TR and privatization.

In order to get a picture of national union activity, we carried out interviews with four national officers (lay elected) and four national officials (paid appointed). The main aim though was to hear from Napo branches about their experiences and those of the members they represent. We conducted 29 branch officer interviews across 17 out of 21 branches. This sample gave us a cross section including female and male Napo branch officers (63/37\% split), outsourced and remaining public sector (52/48\% split) workers, and different grades of probation practitioner represented by Napo. We assured all research participants of anonymity and therefore we do not name individuals or their branches. Combined, the different branches provided geographical spread across the country and different private owners. In three cases, we attended branch meetings (where we had the chance to listen to members articulate their concerns about the post-TR environment) and in one, we held two roundtable discussions that specifically addressed the current challenges and concerns post-TR. 
Through this method, we were also able to observe directly how union officers were responding to member concerns at branch level.

Survey questions were designed according to issues identified once the research got underway, specifically in the interviews and roundtable discussions. The survey enabled us to collect a larger pool of experiences of TR and workplace unionism in the wake of it. The survey was approved by Napo and sent to all members. It attracted 992 responses, representing a $17.5 \%$ response rate of those eligible to take part.

Respondents were distributed across the 21 Napo branches. Their characteristics were quite typical of the probation workforce and of Napo's membership with an overrepresentation of women (68\% of the respondents) and employees aged over 45 years old (63\%), with few dependent children (85\% have less than one child under 16 years old), mostly working full-time (80\%). Probation officers and probation managers were also over-represented in the survey and comprised $74 \%$ of the respondents.

\section{The context of change}

The new structure for probation services is complex and surely constitutes an example of what has been termed 'privatization by stealth' in so far as ultimate ownership and decision-making responsibility remains in the public sector, while a significant component of provision has been relocated to providers outside of the public sector (Burgess and MacDonald 1999: 38). In June 2014, 21 Community Rehabilitation Companies (CRCs), originally owned by the Ministry of Justice, were created to handle low to medium risk offenders in the community. The CRCs were sold to companies/organizations in the private - mainly big multinationals - and third sectors as of $1^{\text {st }}$ February 2015. The CRC ownership contracts are for seven years, renewable. Probation practitioners located in CRCs are employed by the CRC rather than by the 
share owner, but the share owner manages the employment relationship. The National Probation Service (NPS) reporting to the National Offender Management Service (NOMS), an executive agency of the Ministry of Justice, was created to supervise high risk offenders. Probation practitioners located in the NPS are civil servants. Before the split of probation services, the workforce was around 16,000 (full-time equivalent) with approximately 10,000 probation practitioners (in the main roles represented by Napo). Employees were allocated either to the NPS or to their local CRC by $1^{\text {st }}$ June 2014 before the sale of CRC contracts such that they were in place when the new owners took over on $1^{\text {st }}$ February 2015. Probation staff were overwhelmingly opposed to TR. They especially disliked privatization/outsourcing, but they did not want to be civil servants either. The survey shows that $23 \%$ of the respondents allocated to CRCs appealed against their allocation (and only 10\% for NPS). The majority of fully qualified practitioners (Probation Officers (POs)) were allocated to the NPS and 38\% of those allocated to CRCs appealed against this decision. The majority of partially qualified (Probation Service Officers (PSOs)) were allocated to the CRCs. In response to TR, Napo restructured its branches to mirror the CRCs' geographical structure: 21 branches were formed from the previous 35 (which had mirrored the 35 probation trusts in existence prior to TR). This new branch structure aimed to meet the challenge of delivering effective bargaining and representation on behalf of members in the new multi-employer context.

\section{Maintaining local representation in a restructured workplace}

Contrary to bigger unions, Napo has very few national paid officials and relies on an active network of local activists involved in the daily representation of members. The decentralized structure of probation and the possibility for local interpretation in the 
implementation of national collective agreements have contributed to giving power to local branches. Only two of them, with more than 750 members, had full-time chairs (working for Napo on facility time). Most branch officers had less than 50\% facility time. They were well aware of everyday working realities and were able to keep a close connection with members.

Our study showed that, in a context where many professionals expressed anxiety about the future of their working conditions and their job security, local representation was more than ever expected from Napo reps. Table 1 shows survey statements related to reasons for staying in Napo post-TR. Among the possible reasons, advice and support (75\%) and legal representation (71\%) were well ahead of other motives for both men and women. These results confirm other studies undertaken in feminised professions where the demand for member servicing surpasses the development of close social ties between activists and the rank and file in the face of austerity and radical restructuring (Saundry and McKeown, 2013).

\section{TABLE 1}

Branch officers gave accounts of their representation work. The state of uncertainty about working and employment conditions was so high following TR that branch officers and convenors had to work overtime to advise members and reassure them. With the decrease in facility time, some branch officers found it very hard to address all their members' demands.

The instructions now from the MoJ [Ministry of Justice] are that one individual union rep [in NPS], whatever their role, can claim up to $50 \%$ [facility time] but no more than $50 \%$ or as a branch you cannot claim more than $50 \%$ of a full-time role. So that is straining us and that is limiting us incredibly. Where we had a whole role to play with, we've now got half a role. And it's just not possible. With the amount of stress that's going on and consequences of 
stress and staffing capability, disciplinary, we need a lot of time for the reps to help those members. (Female branch officer)

Further, the foreseeable future diversification of the membership's terms and conditions, depending on the different employers' policies, was set to make union representation work more complex for existing well-trained branch officers, but even more so for new reps. One of the main issues facing Napo was that it largely relied on a small pool of older, more senior activists who disproportionately took on the representation role. The survey showed that only $15 \%$ of responding members declared holding a Napo branch or national position. If the level of union density was quite high and used to be very stable (56\% of the survey respondents had been a Napo member for more than 10 years), typical Napo activists were more likely to be middle aged, experienced probation officers. $16 \%$ of men and 14\% of the $46-55$ age group and $15 \%$ of the 56-65+ age group reported having held a branch role compared with $10 \%$ of women and $8 \%$ of the $18-35$ age group (a group that is $80 \%$ feminized). However, these survey results overlook the fact that some Napo branches are exclusively led by women and women's involvement has increased over time (Author $\mathrm{B}, \mathrm{XXXX).}$

Following TR, the concentration of Napo activists within NPS - either because they were initially sifted to NPS or because they managed to transfer post TR - created concerns in terms of branch organization. With just a few exceptions where branches were historically led by PSOs (now mostly sifted to CRCs), some branches were struggling to identify CRC activists. This lack of CRC reps revealed the implicit predominance of fully qualified grades among Napo branch officers (with a few exceptions) (and national lay officers) and is quite concerning for the future of Napo since CRC owners did not accept cross-representation anymore. In most branches, 
Napo officers located in NPS were prevented by now from representing their CRC colleagues.

In terms of local structure, it's a mess at the moment because we are being told that NPS staff cannot represent members of the CRC and yet our branch has unsurprisingly and this is something I was quite interested in looking at when I get a chance; the branch executive predominantly is NPS. And I think the history of that is interesting in that regard because it was a part union and part professional association. So what we have in [our region] is a branch that is very experienced, very strong, quite active and quite resolute, but dominated by people from the NPS. And officially we are now being told that you can no longer represent CRC members, we don't have enough personnel to do the representation if that's the case. (Male branch officer)

This new rule was seen as beneficial to the employers, as very junior union activists had been obliged to fill some branch positions with very little experience.

Consequently, these branch organization issues put a lot of stress on national officers and officials who tried to overcome branch deficiencies by representing individual members on top of their other union roles.

I: And are you seeing differences in those regions, in their ability to cope with what they're facing right now?

Yeah, inevitably a lot of it actually depends on where the activists fell when they were assigned back in June. So in certain areas of the country, we are struggling to have reps either on the CRC side or the NPS side because all the activists went that way or the other. And there's no consistency in where people went. So yeah, we're literally at the point where officials are coming under pressure to start representing individual members which I don't mind doing. (Male national official)

\section{Encouraging union participation amongst a highly feminized workforce}

This situation emphasized the urgency for Napo not only to recruit members, but also to train new activists. All branches seemed well aware of the importance of recruiting 
members. Most of them had completed membership mapping requested by national Napo, even if it was a "painful exercise”.

It was difficult, but we sat down together in the beginning to do the percentages on calculators and things like that. But it was difficult this time, most difficult ever because in the past you had NPS and CRC [workforce data] in front of you ... but this time because of the split a lot of information we want to do with NPS we've got, but with CRC we haven't. So it was completely different, because before all the information was there, and we could just go on the system, type in names, track them, where they were, look up offices. We had a book that had all the offices in there ... but that's useless now because everything has changed. So it's been a nightmare task, a task that I must admit that we kind of think we can’t do that right now, we're really busy. (Female branch officer)

Branches were used to recruiting probation trainees during their induction programme, but this practice was disrupted by the restructuring of the HR function in NPS, and by lack of union access to induction events in some CRCs. Previously, branch officers liaised with local HR officers with whom they typically had good relationships, and organized Napo input to induction programmes. In contrast, they were now confronted with remote HR shared services in NPS, and fragmented HR services in the CRCs. All the same, the prospect of check-off ${ }^{\mathrm{i}}$ ending in NPS and possibly in some CRCs was particularly alarming in a context where the higher instability of the workforce, especially amongst young employees, would require constant recruiting efforts. The other big issue was the necessity of encouraging new (and less new) Napo members to participate. In most branches, union positions were not all filled (or were filled by the same people having multiple roles) and branch officers were struggling to organize branch meetings. The level of members’ participation seemed quite low. Table 1 also suggests that very few members stayed in Napo because they wanted to take part in the union (only 22\% of the survey 
respondents chose this statement). Even branches described as very active had difficulties organising quorate branch meetings.

Very active branch in terms of the exec, the exec is very active, very proactive and we used to have quorate branch meetings, but we haven't had quorate branch meetings now in quite some time ... And so the way it's gone locally I think reflects massively how it's gone nationally to try and get people to meetings. Initially it was said to us, it was pressure of work, because bear in mind we negotiated that people could have that time off, it could be in work time, and then we were told it was pressure of work. Then we were told ... a number of different reasons. But my view that the amount of work that people were expected to do, it was disproportionally high in relation to the hours that they got to do the work in, so they were always putting the Napo meetings to one side which is a shame but it is a fact. (Male branch officer)

Explanations for this low level of participation can be found in work time pressures and the increase of workload, but also in location and time issues, which are particularly apposite constraints for women (Author B, XXXX; Munro 2001). Many branches had merged - and some of them had merged before - and were now covering large regions. As found in many other studies (e.g. Colgan and Ledwith 2000; Author B, XXXX), most branch meetings still happened after work and sometimes in remote locations, especially in rural areas and these issues presented obvious gendered constraints:

Well, the region just in terms of geography ... goes from South Cheshire, so touching like Stoke, Staffordshire, so just North of Birmingham, across to the Scottish Borders on that kind of Western side. That's the size of the NPS region. So it's massive and obviously when you get up to Cumbria, Kendall, Workington, Carlisle, that's almost a different country as opposed to Manchester, Liverpool being 30 miles away from each other ... So it’s a very, very big area. If you've just got to do one grievance, from here to Carlisle, that's a day out. (Male branch officer)

As shown in Table 2, when asked what the branch could do better, issues about organizing meetings at the workplace level and in accessible places were frequently 
cited, especially by women and younger women who were most likely combining work and family (58\% of 18-35 age group were in favour of workplace meetings). Many branches tried to address these issues by organizing the branch differently. Most of them chose to elect two Vice-Chairs, one for NPS and the other for the CRC. However, the reorganization of branches revealed the fact "that the thin layer of activists has gone down to a very thin layer of people that are in the right place", as one national officer put it. Many branches were trying to alternate venues for branch meetings within the region and just a few organized workplace meetings. Video conferences and e-mails were used when possible, but despite these efforts, meetings remained poorly attended. Branches’ existence still depended on a very small pool of activists and the survival of the smallest ones would be at risk in cases where current branch officers retired or left probation:

It actually damaged the branch meetings because wherever you have them people would complain, so we have done workplace meetings. We never actually got massive turnout for our branch meetings. That was never our expectation. But we have an active email system... And our last team meeting was very well attended, our branch meeting very well attended. (Female branch officer)

\section{TABLE 2}

Overall, branch expectations seemed to revolve around organizational issues to improve relations with members more than support or consultation demands (only $23 \%$ of the respondents would like the branch to provide more help), which confirmed that Napo reps were quite legitimate and efficient in their local representative role but also that members' participation, especially women's, was constrained by time and location issues (see also Colgan and Ledwith 2000; Author $\mathrm{B}, \mathrm{XXXX).}$ 


\section{Combining different sources of legitimacy}

Beside local representation activity, the survey results provided other insights on members' expectations towards local union leaders. Whereas the ability to provide advice and support appeared to be central in the construction of union reps’ legitimacy, other expectations of Napo revolved around improving terms and conditions and giving voice to members. Table 1 showed that $42 \%$ of the members expressed their wish that Napo negotiations with the employers improve their terms and conditions ( $46 \%$ of men). Whereas only $20 \%$ of the respondents believed that Napo could fight against redundancies, this scepticism did not prevent members in general expecting Napo national to stand up more to the employers. $65 \%$ of the survey respondents $-63 \%$ of women and $67 \%$ of men, ranked this statement first, way before information on professional issues (39\%). These results confirm other studies that show that the preference for collaborative approaches with the employer do not prevent members from expecting the maintenance of a bargaining power (Greene et al. 2000; Saundry and McKeown, 2013).

Whereas a drift towards depoliticization was sometimes cited by male and some older female officers to explain the lack of young (female) members' participation, the only indicator of political values/views suggested by the survey was the statement "I believe in trade unions” in Table 1. It ranked three among the reasons for staying in Napo (66\% and $74 \%$ of men expressed that opinion). This result suggested that some sort of collectivism still prevailed amongst the workforce, a result that has been confirmed by other studies undertaken in feminized workplaces (Saundry and McKeown, 2013; Taylor and Moore, 2014). This collectivism can be rooted in gender 
and also professional identification. If occupational matters were obviously seen as less of a priority for Napo members at the time of the survey, $40 \%$ of the respondents still identified Napo as the voice for probation (45\% of men) and 34\% believed that Napo provided them with important information about professional issues (see Table 1). The question for Napo seemed to be how to act as a union in addition to being a professional association. The balance between these two roles has changed over the years, as one national officer argued:

Some of the challenges that we're facing is because at some stage in the past and I think I can say it was probably about 15, 20 years ago, Napo decided to get more involved in the TUC.... So until then my impression is Napo was kind of a champion of probation, a professional body that did some union stuff. And then it decided to be a union that did some professional championing...

And I think it was a trend, I think around that time it would definitely have been a trend. There was some of the other craft unions were doing it as well... there was a whole range of small unions joining, getting involved in the TUC. It's interesting, it was also around that time that some of the bigger unions were merging. (Male national officer)

Whereas Napo had succeeded in developing some formalized and informal bargaining activities at the national and local level (Author A and B, XXX), while maintaining its role as professional association, the whole process of restructuring is likely to decentralize and weaken both levels of negotiation, in the public and privatized sectors. Local union representation might then come down to individual support and advice without any opportunity to bargain on broader topics such as pay or working conditions.

\section{Discussion and conclusion}

This article contributes to the workplace unionism resilience debate by offering data from a small feminized, professional union that articulates branch officers' views and 
members' expectations during a period of turbulence caused by restructuring of a public service. Converging with previous studies, it provides evidence for even more accountable and responsive relationships between local reps and their members, following restructuring (McBride, 2010; Darlington, 1995, 1997, 2009). However, it also anticipates major difficulties for Napo's organization and efficacy in the near future, but still predicting resilience at the (public sector) workplace. This article identifies different factors that contribute to the resilience of workplace unionism within Napo. First, the process of restructuring itself and the few resources held by the national paid officials to deal with the new private owners of the outsourced part of the service contributed to putting a strong emphasis on branch officers who have to cope with the prospects of new HR policies and future redundancies. Members' expectations clearly indicated the need for even more effective levels of local representation and support in a context of high turbulence that will more specifically affect young (female) professionals, both in terms of employment conditions and career prospects. As depicted in other studies in feminized workplaces, the kind of local unionism that characterizes Napo is a mix of “relational union organizing” where relationships and getting to know people are intertwined with service and support (Saundry and McKeown, 2013). Second, conditions for union collectivism stem from a strong occupational identity built on the unique employee relations nature of the penal environment "where staff are dealing with those members of society who have rejected the values of that society” (Black, 1995) and the sharing of a strong professional and public sector ethos (Mawby and Worrall, 2013; Author B, XXXX). Moreover, previous research in this environment has argued that there is a gendered moral component underpinning the strength of commitment to the work (Author $\mathrm{B}, \mathrm{XXXX}$ ) and this seemed to endure in the post-TR 
environment among the feminized workforce. Third, the resilience of Napo needs to be set in the context of the legacy of large and confident branches that are typical of an articulate and educated membership (Terry, 1996; Carter and Poynter, 1999) which puts great emphasis on occupational, educational and industrial matters. Again, we underline the feminized membership context and the importance of all three of these areas to women professionals (Author B, XXXX; Healy and Kirton, 2002), including members' expectations that their union will be able to represent workers' concerns both as workers and service providers (Taylor and Moore, 2014). Finally, it is also necessary to take account of the democratic and lay control tradition that characterizes Napo. Previous research on women and unions has shown how gender democracy is enhanced via opportunities for women to participate in multiple union structures and forums (Healy and Kirton, 2000). Napo’s historic and contemporary record on women's representation in decision-making structures compares very well with other small and large unions (Author B, XXXX).

However, some limitations can be predicted for the permanence of effective workplace unionism in probation. So far, a small number of branch officers were key to the resilience of local representation. These activists were handling their union duties in a more demanding context and were managing to retain and recruit members. They had proved Napo’s usefulness to members who displayed strong instrumental and individual expectations towards their union (support, advice, legal help). This effectiveness of branch organization is likely to be affected by difficulties adapting to a more segmented and dispersed constituency resulting from TR and by the foreseeable shortage of experienced activists due to their retirement or voluntary redundancy. The low level of young members' participation, partly due to wellidentified barriers for women's engagement in union activities (Author B, XXXX) 
casts doubt on the potential for member-led renewal for Napo. Finally, if close relationships with members and local representation are the basis of workplace unionism, Napo also has to maintain its capacity to stand up against the employers and to act as a professional body. These three different roles may be difficult to juggle for a small trade union facing the fragmentation of its collective bargaining table (Author A \& B, XXXX) and the reconfiguring of professional standards and career routes.

The case of Napo clearly indicates that the issue of workplace unionism resilience in the public sector needs to be carefully appraised over a long period of time postrestructuring. For a small union like Napo, the effects of restructuring/outsourcing can be so devastating in terms of resources and membership that even a strong workplace unionism tradition can be diluted by the new employers' employment relations strategies. Of course, the possibility of absorption by a large union looms for a small union facing these challenges. Besides, this collective and member-led union culture is linked to the main characteristics of the professional community. If some assume that left wing politicization is usually correlated with a certain type of union practices, we can also accept that certain professional values and ethos also translate into specific union practices. In the case of Napo, the existing activists mostly came from the same generation of probation officers who shared a social worker occupational identity that was also reflected in their perspectives on Napo's purpose and ways of functioning (Author B, XXXX). If TR represents a major challenge for the survival of Napo, the restructuring (and further feminization) of the profession also brings new questions for Napo, both in terms of democratic practices, articulation of occupational and industrial matters and unions priorities. 


\section{References}

Author B (XXXX)

Author A and B (XXXX)

Bach, S. (2016). "Deprivileging the public sector workforce: Austerity, fragmentation and service withdrawal in Britain”. The Economic and Labour Relations Review, 27 (1): 11-28.

Bach, S. and Bordogna, L. (2013). "Reframing public service employment relations: The impact of economic crisis and the new EU economic governance”. European Journal of Industrial Relations, 19(4): 279-294.

Black, J. (1995). “Industrial Relations in the UK prison service”. Employee Relations, 17(2): 64-88.

Brown, W., 2011, "Déclin et refondation de la négociation collective en GrandeBretagne”, L’Homme et la société, 182 : 53-73.

Burchill, F. (1995). "Professional unions in the National Health Service: issues and membership trends”. Review of Employment Topics, 3: 13-43.

Burgess, J. and Macdonald, D. (1999). “Outsourcing, employment and industrial relations in the public sector”. The Economic and Labour Relations Review, 10(1): 36-55.

Butler, P. and Tregaskis, O. (2015) Workplace partnership and legitimacy: a multilayered analysis of the shop steward experience. Work, Employment \& Society, 29 (6). pp. 895-911. 
Carter, B. and Poynter, G. (1999). "Unions in a changing climate: MSF and Unison experiences in the new public sector”. Industrial Relations Journal, 30(5): 499513.

Colgan, F. and Ledwith, S. (2000). “Diversity, Identities and Strategies of Women Trade Union Activists”, Gender, Work and Organization,7(4): 242-257.

Colling, T. (1993). “Contracting Public Services: the Management of Compulsory Competitive Tendering In Two County Councils”, Human Resource Management Journal, 3 (4): 1-15.

Cumbers, A., MacKinnon, D. and Shaw, J. (2010). “Labour, organisational rescaling and the politics of production: union renewal in the privatised rail industry”. Work, employment and society, 24(1): 217-144.

Cunningham, I. and James, P. (2010). "Strategies for Union Renewal in the Context of Public Sector Outsourcing”. Economic and Industrial Democracy, 31(1): 34-61.

Darlington, R. (1993). “The challenge to Workplace Unionism in the Royal Mail”, Employee Relations, 15(5): 3-25.

Darlington, R. (1995). "Restructuring and Workplace Unionism at Manchester Airport”. British Journal of Industrial Relations, 33(1): 93-115.

Darlington, R. (1997). “Workplace union resilience in the Merseyside Fire Brigade”, Industrial Relations Journal, 29(1): 58-73

Darlington, R. (2009). “Leadership and Union Militancy: The Case of the RMT”. Capital and Class, 33 (3): 3-32.

Eurofound (2015). ERM Annual report 2014: Restructuring in the public sector. Luxembourg, Publications Office of the European Union 
Fairbrother, P. (2006). “The Emergence of the "De-Centred” British State”, in P. Fairbrother and A. Rainnie (eds) Globalisation, State and Capital, pp.53-71. London: Routledge.

Fisher, M. (2004). “The crisis of civil service trade unionism: a case study of call centre development in a civil service agency”. Work, employment and society, 18(1): 157-177.

Flecker, J. and C. Hermann (2014). "The liberalization of public services: Company reactions and consequences for employment and working conditions." Economic and Industrial Democracy, 32(3): 523-544.

Gale, J. (2012). “Government reforms, performance management and the labour process: the case of officers in the UK probation service”. Work, employment and society, 26(5): 822-838.

Greene, A.M., Black, J. and Ackers, P. (2000). “The Union Makes Us Strong? A study of the Dynamics of Workplace Union Leadership at Two Uk Manufacturing Plants”, British Journal of Industrial Relations, 38(1): 75-93.

Harrisson, D., Roy, M. and Haines III, V. (2011). “Unions Representatives in LabourManagement Partnerships: Roles and Identity in Flux”. British Journal of Industrial Relations, 49(3): 411-435.

Healy, G. and Kirton G. (2002). "Professional and highly qualified women in unions”, in F. Colgan and S. Ledwith (eds) Gender, Diversity and Trade Unions, pp.186204. London: Routledge.

Healy, G., Bradley, H. and Mukherjee, M. (2004), “Individualism and collectivism revisited: a study of black and minority ethnic women”. Industrial Relations Journal, 35(5): 451-466. 
Kessler, I. and Heron, P. (2001). "Steward organisation in a Professional Union: The case of the Royal College of Nursing”. British Journal of Industrial Relations, 39(3): 367-391.

Lloyds, C. (1997). “Decentralization in the NHS: Prospects for Workplace Unionism”, British Journal of Industrial Relations, 35(3): 427-446.

Mawby, R. and Worrall, A. (2013). Doing probation Work. Identity in a criminal justice occupation. Routledge, New York.

McBride, J. (2004). "Resilience or renewal? The persistence of shop steward organisation in the TMCI”. Capital and Class, 82: 115-142.

Munro, A. (2001). A feminist trade union agenda? The continued significance of class, gender and race. Gender, Work and Organization, 8(4): 454-471.

Saundry R. and Mc Keown, M. (2013). "Relational union organizing in a healthcare setting: a qualitative study”, Industrial Relations Journal, 44(5): 533-547.

Schnabel, C. (2013). “Union membership and density: Some (not so) stylized facts and challenges”. European Journal of Industrial Relations, 19(3): 255-272.

Taylor, P. and Moore, S. (2014). “Cabin crew collectivism: labour process and the roots of mobilization”, Work, employment and society 29(1): 79-98.

Terry, M. (1983). “Shop stewards through expansion and recession”. Industrial Relations Journal 14(3): 49-58.

Terry, M. (1996). “Negotiating the Government of Unison: Union Democracy in Theory and Practice”. British Journal of Industrial Relations, 34(1): 87-110.

Whitfield, D. (2002). “Impact of privatisation and commercialisation on municipal services in the UK”. Transfer: European Review of Labour and Research, 8: 234251. 
Table 1: Reasons to stay in Napo

\begin{tabular}{|c|c|c|c|}
\hline & $\begin{array}{l}\text { Female } \\
\text { N/\% }\end{array}$ & $\begin{array}{l}\text { Male } \\
\text { N/\% }\end{array}$ & Total \\
\hline To provide advice and to support me in case I have a problem at work & $\begin{array}{l}482 \\
68 \\
75\end{array}$ & $\begin{array}{l}228 \\
32 \\
75\end{array}$ & $\begin{array}{l}710 \\
100 \\
75\end{array}$ \\
\hline To provide legal representation in case I have a problem at work & $\begin{array}{l}449 \\
67 \\
70\end{array}$ & $\begin{array}{l}222 \\
33 \\
73\end{array}$ & $\begin{array}{l}671 \\
100 \\
71\end{array}$ \\
\hline I believe in trade unions & $\begin{array}{l}400 \\
64 \\
62\end{array}$ & $\begin{array}{l}225 \\
36 \\
74\end{array}$ & $\begin{array}{l}625 \\
100 \\
66\end{array}$ \\
\hline $\begin{array}{l}\text { I believe Napo negotiations with the employers improve my terms and } \\
\text { conditions }\end{array}$ & $\begin{array}{l}259 \\
65 \\
41 \\
\end{array}$ & $\begin{array}{l}141 \\
35 \\
46 \\
\end{array}$ & $\begin{array}{l}400 \\
100 \\
42 \\
\end{array}$ \\
\hline I believe Napo gives staff a voice in probation & $\begin{array}{l}245 \\
64 \\
38\end{array}$ & $\begin{array}{l}436 \\
36 \\
45\end{array}$ & $\begin{array}{l}381 \\
100 \\
40\end{array}$ \\
\hline Napo provides me with important information about professional issues & $\begin{array}{l}223 \\
70 \\
35\end{array}$ & $\begin{array}{l}97 \\
30 \\
32 \\
\end{array}$ & $\begin{array}{l}320 \\
100 \\
34\end{array}$ \\
\hline I want to take part in the union & $\begin{array}{l}132 \\
62 \\
21\end{array}$ & $\begin{array}{l}80 \\
38 \\
26\end{array}$ & $\begin{array}{l}212 \\
100 \\
22\end{array}$ \\
\hline I believe Napo can fight against redundancies & $\begin{array}{l}122 \\
64 \\
19 \\
\end{array}$ & $\begin{array}{l}68 \\
36 \\
22 \\
\end{array}$ & $\begin{array}{l}190 \\
100 \\
20 \\
\end{array}$ \\
\hline Total & $\begin{array}{l}640 \\
68 \\
100 \\
\end{array}$ & $\begin{array}{l}303 \\
62 \\
100 \\
\end{array}$ & $\begin{array}{l}944 \\
100 \\
100\end{array}$ \\
\hline
\end{tabular}

Table 2: Member expectations of Napo branches

\begin{tabular}{|l|l|l|l|}
\hline & $\begin{array}{l}\text { Female } \\
\text { N/\% }\end{array}$ & $\begin{array}{l}\text { Male } \\
\text { N/\% }\end{array}$ & Total \\
\hline Hold more workplace meetings & 278 & 115 & 394 \\
& 71 & 30 & 100 \\
& 51 & 44 & 49 \\
\hline Hold meetings in more accessible places & 198 & 67 & 265 \\
& 75 & 25 & 100 \\
\hline Stand up more to the employers & 36 & 26 & 33 \\
\hline Consult more with members about local union priorities & 160 & 101 & 261 \\
& 61 & 39 & 100 \\
\hline Provide more support/help to individual members & 29 & 39 & 32 \\
\hline Hold meetings at more convenient times & 154 & 77 & 231 \\
& 67 & 33 & 100 \\
& 28 & 29 & 29 \\
\hline Total & 123 & 59 & 182 \\
& 68 & 32 & 100 \\
\hline
\end{tabular}




\footnotetext{
${ }^{i}$ Under the 'check-off' process - many public sector workers who are union members have their subscriptions taken directly from their salary, administered by their employer. In August 2015, the government announced its intention to end check-off across all public sector organizations.
} 